The Geneva Papers on Risk and Insurance, 22 (No. 84, July 1997) 536-552

\title{
An Analysis of the Difference in Solvency Experience of U.S. and Canadian Life Insurers
}

\author{
by Anne E. Kleffner* and Jerry L. Jorgensen*
}

\section{Introduction}

The Canadian and U.S. life insurance industries are similar in many ways. Both have shifted away from the more profitable, traditional protection-type products toward the more competitive investment or accumulation-type products that have smaller profit margins. As well, the industries in both countries are intensely regulated and very competitive. In one critical area, however, the life insurance industry in Canada appears to enjoy much greater success than in the U.S.: solvency. Sovereign Life Insurance Company, which was seized by federal regulators in December, 1992 was the first failure of a federally incorporated life insurance company in Canada. On August 11, 1994 Confederation Life was seized by federal regulators, marking "the single biggest insurance company failure in North America" (Partridge and Slocum, 1994). Other provincially chartered companies have failed, ${ }^{1}$ such as Les Cooperants Mutual (Quebec) in 1992, but even these have been rare. Since 1970, only six life insurer insolvencies have occurred in Canada (See Table 1).

In contrast, the number of life insurer insolvencies in the U.S. has increased dramatically over the past two decades. During the period 1976-1991, 290 life/health insurers domicilied in the U.S., the District of Columbia and Puerto Rico became insolvent or financially impaired (Best's, 1992). From 1976-1982, an average of 8 per year became financially impaired; from 1983-1988 the average was 15 per year. And in 1989 there were 42 financially impaired companies.

This paper offers explanations for the difference in the frequency of insolvency for Canadian versus U.S. life insurers. Over the period 1976-1991, 4 out of approximately 170 $(2 \%)$ life insurers in Canada were declared insolvent, whereas 290 out of about 2,400 life insurers $(12 \%)$ in the U.S. became insolvent or financially impaired. Differences between

* Anne E. Kleffner is an Associate Professor in Insurance and Risk Management at the University of Calgary. Jerry L. Jorgensen is Professor and Chair in Insurance and Risk Management at the University of Calgary, Alberta, Canada.

The authors wish to thank Alli Nathan, Jan Ambrose, and two anonymous referees for their helpful comments on earlier drafts of this paper. We are also grateful to Brent Ewasiuk who provided invaluable assistance in data collection.

1 The insolvency of provincially incorporated insurers prior to 1992 was mainly attributed to small size and lack of diversification. 
Table 1A: Insolvency experience in Canada

\begin{tabular}{|c|c|}
\hline Year & Number/Jurisdiction \\
\hline 1972 & 2 (Alberta) \\
\hline 1984 & 1 (Alberta) \\
\hline 1992 & 2 (Quebec, Federal) \\
\hline 1994 & 1 (Federal) \\
\hline
\end{tabular}

SOURCE: Financial Post, Superintendents' offices.

Table 1B: Insolvency experience in the U.S.

\begin{tabular}{|c|c|c|c|}
\hline Year & Number & Year & Number \\
\hline 1976 & 5 & 1984 & 11 \\
\hline 1977 & 6 & 1985 & 9 \\
\hline 1978 & 11 & 1986 & 14 \\
\hline 1979 & 7 & 1987 & 20 \\
\hline 1980 & 9 & 1988 & 19 \\
\hline 1981 & 8 & 1989 & 42 \\
\hline 1982 & 10 & 1990 & 41 \\
\hline 1983 & 20 & 1991 & 58 \\
\hline
\end{tabular}

SOURCE: Best's Insolvency Study Life/Health Insurers.

Canada and the U.S., in terms of regulation, changes in the economic environment and the market for life insurance, and insurers' responses to those changes all help to account for the generally stronger financial position of the Canadian life insurance industry over the past twenty-five years.

\section{Explanations for the difference in insolvency experience}

\subsection{Regulatory differences}

Part of the difference in insolvency experience between the U.S. and Canada may be explained by differences in regulation. In Canada, constitutional authority to regulate insurance is shared between the federal and provincial governments. A Canadian insurance company may incorporate under either provincial or federal laws. Most life and health insurers in Canada are federally incorporated. In 1992, out of 148 companies operating in 
Canada, 120 were federally registered. Other than in Quebec, few companies are provincially incorporated. Provinciallly incorporated insurers may operate in other provinces by obtaining a license from those provinces. Those insurers that operate in more than one province are supervised by the province in which the insurer was incorporated.

Generally speaking, whichever level of government has the authority to incorporate an insurance company also has the authority to oversee the operations of the company in order to ensure its solvency. The provincial legislature has exclusive jurisdiction to prescribe the statutory conditions of insurance contracts and exclusive jurisdiction to license insurance agents, brokers, and adjusters, while the federal government has exclusive jurisdiction for registering all insurance companies incorporated or organized outside Canada that do business in Canada. The responsibility of supervising the financial solvency of these companies also exists at the federal level. The provincial Superintendent has all the responsibilities assumed by the federal Superintendent of Insurance for companies operating under a provincial charter. ${ }^{2}$ In the past, visits to the head office of each company to examine the statements of condition were required every three years, and typically took place every two years. Now, companies are examined annually.

In contrast to Canada, regulation of insurers in the U.S. is carried out at the state level. Each state has its own insurance department that is responsible for overseeing the operations and solvency of insurers conducting business in that state. Consequently, federal regulation of insurers in Canada tends to be more consistent than regulation of insurers on a state by state basis in the U.S. The insurance departments of individual states differ a great deal in terms of the expertise and the number of staff available to monitor companies. Due to differences in staffing and funding, Canadian insurers are now examined by regulators every year whereas U.S. insurers are examined every three to four years. This is significant since studies that attempt to predict insolvency for U.S. insurers are only accurate one to two years prior to insolvency (Ambrose and Carroll, 1994; Barniv and Hershbarger, 1990).

Some of the problems that arise due to the inconsistent solvency regulation by U.S. states were addressed by the NAIC beginning in the mid 1980s. These actions were meant to address the increasing incidence of financially impaired companies, partly a function of disparate state solvency monitoring. These actions include:

- In 1985 the NAIC adopted the Model Regulation to Define Standards and Commissioner's Authority for Companies Deemed to be in Hazardous Financial Conditions. This specifically defines standards of hazardous financial condition, where continued operation is viewed as hazardous to the public or to its policyowners.

- The NAIC established Financial Regulatory Standards to serve as baseline standards to encourage states to upgrade the quality of insurance solvency regulation (NAIC Standards and Accreditation Program). In 1990 the NAIC adopted an accreditation program to provide an incentive for states to improve their solvency regulatory programs to meet NAIC standards (McGill, 1994).

2 Each province has an agency responsible for administering the provincial insurance laws, usually called the Office of the Superintendent of Insurance. The Superintendents form a collective body similar to the U.S. National Association of Insurance Commissioners (NAIC) called the Canadian Council of Insurance Regulators (CCIR). The CCIR recommends uniform insurance legislation that may be adopted by the common law provinces and the two territories. 
The NAIC's attempt to achieve a degree of uniformity in regulation provides some evidence that federal regulation of insurers in Canada helps to circumvent certain problems that are created by dissimilar state regulation in the U.S. ${ }^{3}$

Another important difference relates to the timeliness of regulation in Canada and the U.S. Canadian regulation has tended to be more proactive than regulation in the U.S. and more responsive to changing market conditions. This has helped to alleviate the problem of having to create or adjust regulation only after a particular problem has developed in terms of insurers' solvency. The importance of addressing changing market conditions early rather than adopting measures only after a problem has developed is emphasized by the findings of Kopcke and Randall (1991). They examined a sample of U.S. life insurers that showed very rapid growth, unusual concentrations in the riskier asset categories or well publicized solvency problems, and found a consistent pattern of risk taking for a number of insurance companies. This pattern included several years of rapid growth in one or a few types of very risky assets that lead to abnormal risk concentrations; profitable operations and maintenance of satisfactory capital ratios; a turning point in economic circumstances, adversely affecting the areas of risk concentration; an accelerating loss of value in the risky asset categories, eventually resulting in falling capital ratios; and liquidity pressures as customers rushed to withdraw funds, forcing the insurer to sell assets at a loss.

As mentioned, although insurers that were heavily invested in risky assets were able to meet capital ratio requirements for a period of time, eventually such investments led to their demise. The general problem regarding capital ratios as a measure of solvency is that capital ratios fall only after losses develop, and well after the risk exposure has been assumed. Hence, it is difficult to detect a declining strategic position until it is too late. Thereore, the need for appropriate and timely regulation that reflects current as well as evolving market conditions is critical.

Three instances of Canadian regulations being more proactive than in the U.S. pertain to investment guidelines, policy loan interest rates, and the valuation of liabilities. Until 1992, insurance regulation in Canada provided qualitative tests and some quantitative limits regarding the types of investments that life insurers could purchase. The authorized investments and their limits were similar to those in place in the U.S. until the early 1980 s when the regulation of U.S. life insurers' investments began a period of substantial liberalization. Many of the quantitative rules for investment were liberalized, permitting U.S. insurers to invest larger portions of assets in riskier types of securities. In 1983, the "prudent man" rule was introduced in the U.S. and substituted for many of the specific guidelines within each category of permitted assets. The qualitative standards were removed, but quantitative standards remained in place. As a consequence, a number of insurers became heavily invested in junk bonds, and when the junk bond market collapsed, these insurers were severely undercapitalized.

In response to the increase in insurer insolvencies in the 1980s, U.S. regulators did a number of things. Concerning the increased investment in junk bonds, New York, in 1987, was the first state to impose a 20 percent limit on "high yield, high risk" obligations, either

${ }^{3}$ Federal regulation in Canada is arguably more practical than it is in the U.S. given the smaller size of the Canadian insurance industry. The Canadian life insurance industry is about one tenth the size of the U.S. industry and it would be difficult, if not impossible, to have 12 efficient provincial/territorial insurance department effectively monitoring company solvency. 
publicly traded or issued in a leveraged buyout (Wright, 1991). Eventually the limit was applied to all private placements and to all medium grade bonds. Other states adopted similar limits. Further, the NAIC increased the required formula contributions to the Mandatory Security Valuation Reserve (MSVR) ${ }^{4}$ effective year end 1990; wrote a Model Investment Law that carefully defined allowed asset classes and established concentration limits within each class; and required an asset valuation reserve that addresses all classes of invested assets and requires both formula contributions and capital gains to be reserved.

In contrast to what was happening in the U.S., the liberalization of investment restrictions did not occur until 1992 in Canada and was accompanied by Minimum Continuing Capital and Surplus Requirements (MCCSR), a risk-based capital adequacy formula. The implementation of MCCSR in conjunction with liberalizing investment regulation by the adoption of the prudent person standard is notable. It provided a level of safety and imposed a discipline that did not exist in the U.S. until 1992 when the NAIC adopted risk-based capital requirements. Relating capital requirement to risk demands that companies that adopt higher risk strategies also hold higher levels of capital in order to provide an acceptable level of safety.

Although it appears that some of the actions taken by U.S. regulators were reactive, and in response to the financial problems that a number of insurers were facing, it is debatable whether or not the judgment of regulators should be substituted for the judgment of insurance company management, the competitive market or the financial market. However, even under the assumption that management makes decisions to maximize value and therefore takes into consideration the risk/return trade-offs that exist for new or existing strategies, it seems that in some instances companies themselves do not fully understand some of the things they do until after problems develop (Cohen, 1991). ${ }^{5}$ Furthermore, the existence of state guaranty funds that create an implicit "put option" produce an incentive for insurance companies to take on a greater amount of risk than in the absence of such funds. ${ }^{6}$ Hence, the party that has to bear the potential burden of the option has an interest in designing regulations that limit the number and size of claims that will be paid by the fund.

Another important difference in the timeliness of regulation relates to the interest rates that could be charged to policyholders who borrowed against their cash value policies. In the U.S., policyholders could borrow at a guaranteed rate of only 5-6\% until flexible interest rates were adopted in $1980 .{ }^{7}$ When interest rates soared in the $1970 \mathrm{~s}$, insurers experienced

4 The MSVR, introduced in 1951, is an amount designated as a cushion for any large changes in the valuations of investments. It prevents insurers from appearing to have excessive instability due to changes in the market value of common stocks. Two reserves replaced the MSVR in 1991: the asset valuation reserve and the interest maintenance reserve.

${ }^{5}$ For example, when companies shifted their product mix from whole life insurance to shorterterm, less profitable products such as universal life and guaranteed investment contracts (GICs), this changed the nature of the risk insurers had to manage and it took time for them to develop the required expertise.

${ }^{6}$ Evidence from the banking industry and the savings and loan crisis is supportive of the claim that the presence of guaranty funds result in excessive risk taking by intermediaries. Non-risk-based guaranty fund assessments allow undercapitalized companies to compete against stronger companies using the protection of the guaranty fund (Moloney, 1992).

7 On December 3, 1980 the National Association of Insurance Commissioners adopted model regulation allowing life insurance companies to charge variable policy loan interest rates. 
substantial disintermediation as policyholders took out policy loans at 5-6\% in order to invest at rates in excess of $15 \%$. This demand by policyholders for their cash values represented a shortening of insurers' liabilities, which presented a problem for insurers since a large portion of their assets was tied up in long-term, low yieldings assets. ${ }^{8}$ In contrast to the U.S. experience, flexible policy loan rates were introduced in Canada in 1968 and this moderated disintermediation as interest rates rose. Table 2 helps to demonstrate the adverse

Table 2:

Distribution of assets of Canadian life insurance companies (\%)

\begin{tabular}{cccccccc}
\hline Year & Bonds & Stocks & $\begin{array}{c}\text { Mortgage } \\
\text { Loans }\end{array}$ & $\begin{array}{c}\text { Real } \\
\text { Estate }\end{array}$ & $\begin{array}{c}\text { Policy } \\
\text { Loans }\end{array}$ & $\begin{array}{c}\text { Other } \\
\text { Assets }\end{array}$ & Total \\
\hline 1970 & 37.0 & 6.9 & 43.2 & 4.6 & 5.0 & 3.2 & 100.0 \\
1975 & 37.1 & 10.2 & 38.7 & 5.2 & 4.8 & 4.0 & 100.0 \\
1980 & 37.1 & 12.6 & 36.6 & 4.0 & 4.2 & 5.4 & 100.0 \\
1981 & 37.5 & 11.1 & 35.4 & 4.6 & 4.8 & 6.5 & 100.0 \\
1982 & 38.3 & 11.0 & 33.7 & 5.2 & 4.7 & 7.1 & 100.0 \\
1983 & 38.8 & 12.5 & 32.8 & 5.6 & 4.2 & 6.1 & 100.0 \\
1984 & 42.0 & 11.6 & 30.6 & 5.4 & 3.8 & 6.6 & 100.0 \\
1985 & 44.2 & 11.2 & 29.7 & 5.0 & 3.3 & 6.6 & 100.0 \\
1986 & 42.9 & 11.7 & 31.3 & 4.6 & 3.0 & 6.4 & 100.0 \\
1987 & 41.9 & 11.5 & 32.4 & 4.8 & 2.8 & 6.8 & 100.0 \\
1988 & 41.2 & 11.5 & 32.9 & 4.8 & 2.5 & 7.1 & 100.0 \\
1989 & 38.9 & 12.0 & 34.8 & 5.0 & 2.3 & 7.1 & 100.0 \\
1990 & 39.2 & 10.8 & 35.8 & 5.1 & 2.2 & 6.8 & 100.0 \\
1991 & 40.2 & 11.7 & 34.5 & 5.5 & 2.1 & 6.0 & 100.0 \\
1992 & 40.3 & 12.6 & 32.6 & 6.3 & 1.9 & 6.3 & 100.0 \\
\hline
\end{tabular}

Source: Canadian Life and Health Insurance Facts

\begin{tabular}{cccccccc}
\multicolumn{7}{c}{ Distribution of assets of U.S. life insurance companies (\%) } \\
Year & Bonds & Stocks & Mortgages & Estate & Loans & Assets & Total \\
\hline 1970 & 40.6 & 7.4 & 35.9 & $*$ & 7.8 & 8.3 & 100.0 \\
1975 & 41.8 & 9.7 & 30.8 & 3.3 & 8.5 & 5.9 & 100.0 \\
1980 & 44.4 & 9.9 & 27.4 & 3.1 & 8.6 & 6.6 & 100.0 \\
1981 & 44.4 & 9.1 & 26.2 & 3.5 & 9.3 & 7.6 & 100.0 \\
1982 & 45.6 & 9.5 & 24.1 & 3.5 & 9.0 & 8.3 & 100.0 \\
1983 & 47.1 & 9.9 & 23.1 & 3.4 & 8.3 & 8.3 & 100.0 \\
1984 & 49.6 & 8.8 & 21.7 & 3.6 & 7.5 & 8.8 & 100.0 \\
1985 & 51.0 & 9.4 & 20.8 & 3.5 & 6.6 & 8.7 & 100.0 \\
1986 & 51.9 & 9.7 & 20.7 & 3.4 & 5.8 & 8.6 & 100.0 \\
1987 & 53.3 & 9.3 & 20.4 & 3.3 & 5.1 & 8.6 & 100.0 \\
1988 & 54.9 & 8.9 & 20.0 & 3.2 & 4.6 & 8.4 & 100.0 \\
1989 & 55.1 & 9.7 & 19.6 & 3.1 & 4.4 & 8.2 & 100.0 \\
1990 & 56.4 & 9.1 & 19.2 & 3.1 & 4.4 & 7.8 & 100.0 \\
1991 & 57.6 & 10.6 & 17.1 & 3.0 & 4.3 & 7.4 & 100.0 \\
1992 & 59.5 & 11.6 & 14.8 & 3.0 & 4.3 & 6.8 & 100.0 \\
\hline
\end{tabular}

Source: Life Insurance Fact Book $\quad{ }^{*}$ In 1970 the amount of real estate held was included in the other assets total.

8 Bernier and Kleffner, 1989, find that the change from fixed to variable rate policy loans resulted in an abnormal positive return for U.S. life insurers. This underscores the advantage enjoyed by Canadian insurers since 1968. 
effect on U.S. insurers of having fixed policy loan interest rates. In Canada, the percentage of assets represented by policy loans has fallen steadily from $5 \%$ in 1970 to $1.9 \%$ in 1992 . In contrast; U.S. life insurers experienced an increase in demand for policy loans in the early 1980s when interest rates were high, and policy loans hit a peak of $9.3 \%$ of assets in 1982 . The percentage has been declining since then, and in 1992 was $4.3 \%$, still more than double the Canadian amount. As interest rates rose, it was more difficult for U.S. insurers to provide attractive rates of return to their policyholders due to their forced investment in policy loans. As a result, U.S. insurers were subject to a much higher outflow of funds than were Canadian insurers.

Finally, there has been a significant difference between Canada and the U.S. in terms of the valuation of life insurers' liabilities. In the U.S. regulators prescribed the assumptions insurers were to use for the purpose of calculating policy reserves, and such rigid valuation standards consequently did not accommodate the individual circumstances of particular companies. In contrast, the 1978 amendments to the Canadian and British Insurance Companies Act abolished the strict reserve requirements that insurers had been subject to and replaced them with a system that allowed companies some flexibility, subject to approval by an independent actuarial audit. Prior to the 1978 revisions, valuation methods and assumptions were specified in the Federal Insurance Act or approved by the Superintendent. The 1978 revisions introduced the concept of a Valuation Actuary, appointed by the Board of Directorts, who would also have responsibilities to the Superintendent to produce a report on actuarial reserves. Freedom was giving to the Valuation Actuary to choose valuation methods and assumptions that were "appropriate", rather than having them dictated to them. The creation of the Variation Actuary in Canada is indicative of the forward-looking focus of the Canadian actuarial practice and regulatory oversight in contrast to the "legal compliance" focus of U.S. regulators. ${ }^{9}$ In addition to the valuation of policy reserves, Canadian insurers also enjoyed flexibility in terms of establishing market based surrender values as opposed to the stringent non-forfeiture requirements imposed on U.S. insurers.

\subsection{Market factors}

Over the past three decades, Canada and the U.S. have had similar experience in terms of overall macroeconomic trends, deregulation of the financial services sector, and the resulting effects on the life insurance industry. Beginning in the late 1960s, increasing and more volatile interest rates resulted in problems for insurers as consumers began demanding more than the minimum rates guaranteed on their permanent insurance contracts. Although the traditional fixed-dollar life insurance product worked well in a low inflation environment with moderate interest rates, as the climate changed, insurers had to develop new products in order to compete with other financial service providers for customers' savings. Insurers began to experience asset/liability mismatch problems since assets were invested for the long-term and liabilities were becoming more short-term due to the demand for policy loans, surrenders, and products such as Guaranteed Investment Contracts. In order to combat the problem, insurers began to offer interest sensitive and investment oriented products,

${ }^{9}$ The Insurance Companies Act of 1992 further shifted the responsibility for the solvency of a life insurance company to the appointed Actuary who has the responsibility to report any deterioration in the financial health of the company to the Superintendent of Financial Institutions should the Board of Directors fail to take action to correct the situation when brought to its notice by the Actuary. 
such as universal and variable life, that would allow consumers to earn rates of return commensurate with market rates. The competition with other financial institutions for consumers' savings dollar put pressure on insurers to provide higher returns in order to remain competitive, prompting some insurers to increase their investment in risky assets. The percentage of insurers' premiums from annuities was also increasing relative to life insurance premiums due to a shift in demographics and increased competition. This new line of products offered by insurers had a much slimmer profit margin than traditional life insurance products, making it more difficult for insurers to earn an adequate return on their capital.

\subsubsection{Shift in product mix}

Although the overall picture looked very similar, there were important differences between the U.S. and Canada in terms of the need for, nature of, and timing of insurers' response to the changing market place. One fundamental difference can be found when looking at conventional life insurance policies offered in Canada compared to the U.S. conventional life insurance policies. Those in Canada were more flexible than those offered in the U.S., providing more attractive rates of return, and making them less subject to surrender and lapse when interest rates rose. Canadian insurers, whether mutual or stock, issued both participating and non-participating policies. This is different from the U.S. where mutual insurers' principal product was participating whole life and stock insurers traditionally sold non-participating policies. Consequently, stock insurers had a difficult adjustment to make when non-participating whole life insurance was no longer attractive due to rising interest rates. As the demand for guaranteed interest products, such as whole life insurance, began to dwindle, insurers with large shares in such products suffered the most.

Table 3 illustrates the shift in insurers' product mix due, in part, to more volatile and increased interest rates. The percentage amount in various types of life insurance for Canadian and U.S. insurers is shown. Whole life insurance represented $38 \%$ of the amount of life insurance in Canada in 1983 while it had fallen to only $17 \%$ in the U.S. For the next 3 years, the percent in Canada was at least double what it was in the U.S., most of the difference being made up in universal life, a product that places greater pressure on insurers to credit high rates of interest. This was a critical period for life insurers. New products and a shift in their product mix required adjustments to their investment strategies. The large percentage of U.S. insurers' business represented by universal life during the mid-80s presented them with new and difficult challenges. The effect this had on them is described in detail below.

In comparison to the experience of U.S. insurers, the more gradual shift away from traditional life products in Canada helped to mitigate problems stemming from the shortening of liabilities due to large amounts of surrenders. Other factors also helped to make the shortening of liabilities in Canada less severe than in the U.S. . Flexible policy loan interest rates, smart product design that reduced the incentive to cancel for cash, and the absence of a legal requirement to include certain formula types of nonforfeiture benefits all helped to reduce disintermediation problems for Canadian insurers. Since the duration of liabilities was reduced more gradually in Canada, the asset/liability mismatch problems experienced by life insurers were also less severe than in the U.S.

The shift in insurers' product mix also involved a shift away from the more profitable life insurance products toward more competitive investment and accumulation-type products. This shift came earlier in Canada because of limited potential for growth in traditional 


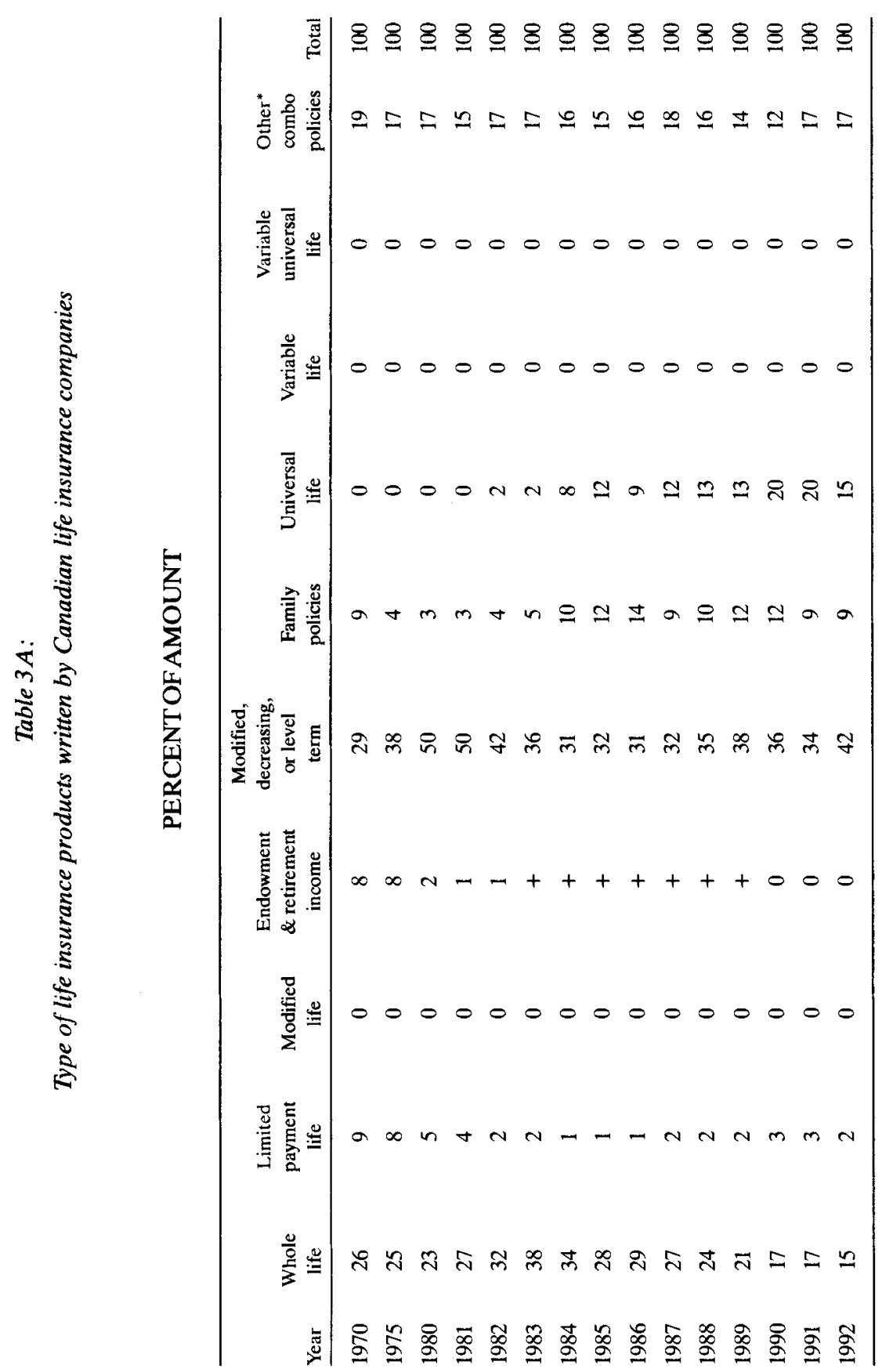




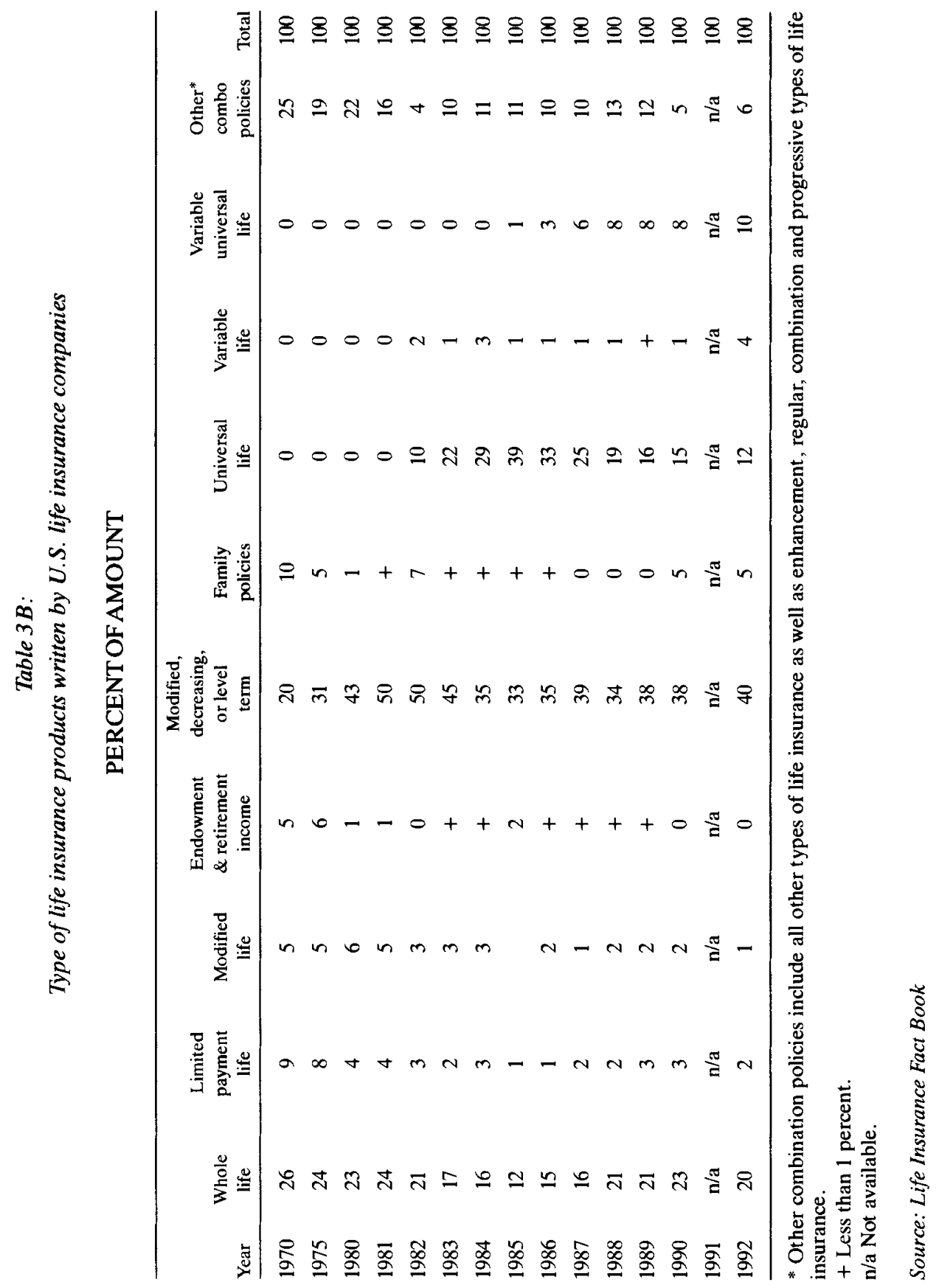


life and health insurance products. A shift in demographics, an aging population and a declining birthrate all favoured accumulation type products, resulting in companies increasing their marketing emphasis on retirement and pension products. As well, the tax deferral incentives of Registered Retirement Savings Plans (RRSPs) made a significant contribution to the growth of annuities in Canada. Even after 1982 when certain annuities became subject to less favourable tax status, RRSPs maintained their exemption from accrual taxation, making them extremely popular savings products. These products were less profitable than traditional products, however, and made it more difficult for insurers to maintain adequate capital ratios.

Due to earlier market saturation in terms of life products in Canada, the Canadian life insurance industry had to make the transition toward lower margined products earlier than the U.S. industry. As early as $1975,31 \%$ of Canadian insurers' premium income was derived from annuities, compared to only $17.4 \%$ in the U.S. By 1981 this percentage rose to almost $45 \%$ for Canadian insurers and $26 \%$ for U.S. insurers (See Table 4 ). ${ }^{10}$

Given their earlier move into the more competitive, lower profit margined products, Canadian insurers became accustomed to operating with slimmer margins sooner than their U.S. counterparts. During the period of investment liberalization in the U.S., insurers experienced a substantial jump in the percentage of their business derived from annuities, jumping $6 \%$ in 1984 and almost $9 \%$ in 1986. While U.S. insurers were taking on more risk in their asset portfolios, they were also subjected to narrow profit margins on a large portion of their business. These two factors together put substantial pressure on insurers' capital position, particularly when they suffered losses on their asset portfolios.

Canadian and U.S. life insurers also experienced differences in terms of pressure to earn high rates of return. The Canadian life insurance industry did not move as early into "investment" products versus "savings" products as did U.S. insurers. Universal life first appeared in Canada in 1983 after first being introduced in the U.S. in the mid-1970s. However, given the flexibility of conventional life insurance policies in Canada, it did not become as popular as quickly as it did in the U.S. Policyholders in the U.S. took advantage of the ability to enjoy tax sheltered growth in a universal life policy and this contributed to the use of such policies as investment products as well as insurance products. Table 3 shows that by 1984 , almost $30 \%$ of U.S. life insurance was in universal life, compared to only $8 \%$ in Canada. Since universal life represented a much smaller percent of life insurance in Canada, there was less pressure on insurers to provide increased, high investment returns, and less incentive to invest in highly speculative assets or mismatch assets and liabilities to take advantage of long-term interest rates.

\subsubsection{Shift in investment strategy}

The declining popularity of traditional life products and the increasing importance of interest sensitive and investment oriented products demanded that insurers provide competitive and attractive rates of return. In the U.S. this resulted in some insurers investing in low grade bonds that provided very high return - until the market crashed. For example,

10 Canadian insurers are also more heavily concentrated in fee-based products, primarily supplemental major medical coverage, disability income coverage and dental coverage. 
Table 4A:

Distribution of premium income of Canadian life insurance companies (\%)

\begin{tabular}{ccccc} 
Year & $\begin{array}{c}\text { Life insurance } \\
\text { premiums }\end{array}$ & $\begin{array}{c}\text { Annuity } \\
\text { premiums }\end{array}$ & $\begin{array}{c}\text { Health insurance } \\
\text { premiums }\end{array}$ & Total \\
\hline 1970 & 63.4 & 19.1 & 17.5 & 100.0 \\
1975 & 49.0 & 31.2 & 19.8 & 100.0 \\
1980 & 39.3 & 38.8 & 21.9 & 100.0 \\
1981 & 35.9 & 44.5 & 20.5 & 100.0 \\
1982 & 35.4 & 41.8 & 22.7 & 100.0 \\
1983 & 36.6 & 39.3 & 24.1 & 100.0 \\
1984 & 34.3 & 42.1 & 23.6 & 100.0 \\
1985 & 31.8 & 45.9 & 22.3 & 100.0 \\
1986 & 32.4 & 47.8 & 19.8 & 100.0 \\
1987 & 30.9 & 50.2 & 18.8 & 100.0 \\
1988 & 30.7 & 49.4 & 19.9 & 100.0 \\
1989 & 29.8 & 50.1 & 20.1 & 100.0 \\
1990 & 29.0 & 51.2 & 19.8 & 100.0 \\
1991 & 28.7 & 51.6 & 19.7 & 100.0 \\
1992 & 29.6 & 50.8 & 19.6 & \\
\hline
\end{tabular}

Note: Prior to 1986, the figures represent the total health insurance premiums of both life insurers and property, casualty and specialty insurers.

Source: Canadian Life and Health Insurance Facts

Table 4 B:

Distribution of premium income of U.S. life insurance companies (\%)

\begin{tabular}{ccccc} 
Year & $\begin{array}{c}\text { Life insurance } \\
\text { premiums }\end{array}$ & $\begin{array}{c}\text { Annuity } \\
\text { premiums }\end{array}$ & $\begin{array}{c}\text { Health insurance } \\
\text { premiums }\end{array}$ & Total \\
\hline 1970 & 59.0 & 10.1 & 30.9 & 100.0 \\
1975 & 50.1 & 17.4 & 32.6 & 100.0 \\
1980 & 44.1 & 24.2 & 31.7 & 100.0 \\
1981 & 43.8 & 26.1 & 30.1 & 100.0 \\
1982 & 42.2 & 28.8 & 29.0 & 100.0 \\
1983 & 42.2 & 25.7 & 32.1 & 100.0 \\
1984 & 38.0 & 31.8 & 30.2 & 100.0 \\
1985 & 38.6 & 34.6 & 26.8 & 100.0 \\
1986 & 34.1 & 43.1 & 22.8 & 100.0 \\
1987 & 36.0 & 41.6 & 22.3 & 100.0 \\
1988 & 32.1 & 45.1 & 22.8 & 100.0 \\
1989 & 30.0 & 47.1 & 22.9 & 100.0 \\
1990 & 29.0 & 48.9 & 22.1 & 100.0 \\
1991 & 30.1 & 46.9 & 23.1 & 100.0 \\
1992 & 29.7 & 47.0 & 23.2 & \\
\hline
\end{tabular}

Source: Life Insurance Fact Book 
First Executive and First Capital were heavily concentrated in either junk bonds or leveraged buyouts in the range of $40-50 \%$ of invested assets (Kopcke and Randall, 1991). Table 5 shows the breakdown of insurers' bond portfolios for the period 1982-1992. Partly due to increased investment in the junk bond market, U.S. insurers had $41 \%$ of their assets invested in corporate bonds in 1988 , or $75 \%$ of their total bond portfolio, compared to about $20 \%$ in Canada. Although Canadian insurers have not had substantial investments in the junk bond market, they have been more heavily invested in mortgage loans than U.S. insurers. However, Canadian insurers were subject to lower interest rate risk because they typically fixed the interest rate for a shorter period of time, such as 6 months to 5 years, compared to the 30 year mortgages that were common in the U.S. In addition, Canadian insurers are more concentrated in the less risky, residential mortgages than U.S. insurers. ${ }^{11}$

\section{Table 5:}

\begin{tabular}{|c|c|c|}
\hline \multicolumn{3}{|c|}{$\begin{array}{l}\text { Distribution of bonds of } \\
\text { Canadian life insurers (\%) }\end{array}$} \\
\hline Year & $\begin{array}{l}\text { Government } \\
\text { securities }\end{array}$ & $\begin{array}{l}\text { Corporate } \\
\text { bonds }\end{array}$ \\
\hline 1982 & 47.0 & 53.0 \\
\hline 1983 & 49.0 & 51.0 \\
\hline 1984 & 54.0 & 46.0 \\
\hline 1985 & 57.5 & 42.5 \\
\hline 1986 & 55.5 & 44.5 \\
\hline 1987 & 54.0 & 46.0 \\
\hline 1988 & 50.5 & 49.5 \\
\hline 1989 & 47.0 & 53.0 \\
\hline 1990 & 43.0 & 57.0 \\
\hline 1991 & 44.0 & 56.0 \\
\hline 1992 & 48.0 & 52.0 \\
\hline
\end{tabular}

\begin{tabular}{|c|c|c|}
\hline \multicolumn{3}{|c|}{$\begin{array}{l}\text { Distribution of bonds of } \\
\text { U.S. life insurers (\%) }\end{array}$} \\
\hline Year & $\begin{array}{l}\text { Government } \\
\text { securities }\end{array}$ & $\begin{array}{c}\text { Corporate } \\
\text { bonds }\end{array}$ \\
\hline 1982 & 20.7 & 79.3 \\
\hline 1983 & 24.8 & 75.2 \\
\hline 1984 & 27.8 & 72.2 \\
\hline 1985 & 29.6 & 70.4 \\
\hline 1986 & 29.7 & 70.3 \\
\hline 1987 & 27.2 & 72.8 \\
\hline 1988 & 25.0 & 75.0 \\
\hline 1989 & 24.9 & 75.1 \\
\hline 1990 & 26.6 & 73.4 \\
\hline 1991 & 30.2 & 69.8 \\
\hline 1992 & 32.3 & 67.7 \\
\hline
\end{tabular}

Gross flows of mortgages of Canadian life insurers (\%)

\begin{tabular}{ccc} 
Year & Commercial & Residential \\
\hline 1984 & 50.0 & 50.0 \\
1985 & 53.0 & 47.0 \\
1986 & 56.0 & 44.0 \\
1987 & 59.0 & 41.0 \\
1988 & 62.0 & 38.0 \\
1989 & 63.0 & 37.0 \\
1990 & 63.0 & 37.0 \\
1991 & 64.0 & 36.0 \\
1992 & 66.0 & 34.0 \\
\hline
\end{tabular}

Gross flows of mortgages of U.S. life insurers $(\%)$

\begin{tabular}{ccc} 
Year & Commercial & Residential \\
\hline 1984 & 83.0 & 17.0 \\
1985 & 86.0 & 14.0 \\
1986 & 87.8 & 12.2 \\
1987 & 89.1 & 10.9 \\
1988 & 90.5 & 9.5 \\
1989 & 91.2 & 8.8 \\
1990 & 91.5 & 8.5 \\
1991 & 92.0 & 8.0 \\
1992 & 91.6 & 8.4 \\
\hline
\end{tabular}

${ }^{11}$ Asset default risk for commercial mortgages is higher, as evidenced by greater capital requirements under risk based capital standards (Pedoe and Rudd, 1993). 
While some U.S. insurers were heavily invested in junk bonds during the 1980 s, the Canadian insurance market did not have many investment related problems other than commercial real estate. Below investment grade bonds are not a market of any significant size in Canada and this has helped Canadian life insurance companies to maintain strong investment portfolios in contrast to their U.S. counterparts. ${ }^{12}$ Some of the differences in investment problems may be related to the lack of breadth of the Canadian capital market, yet this probably is not sufficient to explain the marked difference in terms of asset quality problems experienced by Canadian as compared to U.S. life insurers. As mentioned previously, while investment regulations for U.S. insurers had been liberalized substantially during the 1980s, Canadian insurers were still governed by fairly stringent guidelines until 1992 when both the prudent person rule and MCCSR were adopted. U.S. insurers also had greater pressure to invest in high risk, high return assets due to the large amount of universal life insurance and guaranteed interest products in their portfolios.

The pressure experienced by insurers to earn high rates of return is not only a function of the types of policies offered, but also the way the policies are designed. In contrast to U.S. insurers, Canadian insurers had a liability structure that was "soft" enough to offer a measure of protection as interest rates changed. In other words, they had the ability to adjust credited interest rates on their products as market interest rates changed. Book value guarantees on annuities and Guaranteed Investment Contracts (GICs) and large deposit windows are virtually nonexistent in the Canadian market and Single Premium Deferred Annuities (SPDAs) were eliminated in 1981. Insurers in the U.S., however, had a large portion of their liabilities in guaranteed interest products, resulting in the insurance company bearing the brunt of unfavourable changes in interest rates. As insurers increased their concentration in SPDAs, GICs, and annuities, there was more pressure to take on more investment risk than when protection products dominated the business. SPDAs, though not guaranteeing a high rate of interest, did not have a significant penalty for surrender, making insurers vulnerable to both interest rate risk and liquidity risk. Insurers needed to invest funds in intermediate to long-term assets in order to provide a competitive interest rate, yet this created problems as contract holders surrendered their annuities. GICs, on the other hand, guarantee a rate of interest for the length of the contract and even though insurers developed the expertise to hedge against interest rate risk, they were exposed to a much greater degree of credit risk than with either life insurance or SPDAs (Schneider, 1991).

Finally, the incentive for U.S. insurers to increase the level of risk in their portfolios, especially during the 1980 s, was also compounded by the existence of state guaranty funds which began to be established in the early 1970s. These funds allow insolvent companies to "put" their obligations to solvent companies via the guaranty fund. Such a protection scheme was not adopted in Canada until 1989 when the Canadian Life and Health Insurance Association (CLHIA) established the Canadian Compensation Corporation (CompCorp). ${ }^{13}$

12 Standard and Poor's (1992) and Dominion Bond Rating Service (1993) both have concluded that the asset portfolios of Canadian life insurers have been of better quality than U.S. life insurers.

${ }^{13}$ CompCorp is a federally incorporated, non-profit corporation that provides protection to customers in the event that a Canadian life insurance company becomes insolvent. All companies must be members, and members are assessed for the amounts required to provide the guarantees. 


\section{Summary and discussion}

The marked difference in the occurrence of insolvent life insurers in Canada compared to the U.S. is a function of many different factors. First, federal regulation of insurers in Canada is more consistent than regulation of insurers on a state by state basis in the U.S. . Canadian regulation also appears to have been more timely and proactive than in the U.S., particularly with regard to risk based capital standards, flexible policy loan interest rates and the valuation of liabilities. Other important differences relate to the relative effects on insurers due to a changing economic environment and a shift in demographics. As interest rates rose and became more volatile, traditional fixed rate life insurance products became unattractive. Insurers experienced disintermediation and asset/liability mismatch problems as policyholders surrendered their policies or took out policy loans. The effect in Canada, however, was less severe due to greater flexibility in traditional products. As well, U.S. insurers experienced much stronger pressure to increase investment returns due to a larger percentage of business in universal life insurance and guaranteed interest products. Less pressure to provide high investment returns and the adoption of risk based capital requirements at a time when asset guidelines were liberalized has helped Canadian insurers to maintain, on average, higher quality asset portfolios than their U.S. counterparts.

According to the 1992 Best's Insolvency Study, a number of company characteristics are significantly related to the occurrence of Financially impaired companies (FIC's) in the U.S. over the period 1976-1991. These include small size (companies with less than $\$ 5$ million in capital and surplus have accounted for $74 \%$ of the FICs) and ownership structure (stock insurers account for a disproportionate share of the FICs and the average FIC frequency for stock companies was more than twice the rate for mutual companies). It is understandable that these two factors have been more important in the U.S. than in Canada. As noted previously, few companies in Canada are provincially incorporated, and federally incorporated companies must have capital and surplus in excess of $\$ 6$ million. This essentially eliminates the "small" category of insurers in Canada. Secondly, stock insurers in Canada were not hit as hard by disintermediation problems caused by rising interest rates since they have always offered participating insurance, unlike U.S. stock insurers.

Best's also identifies the primary causes of FICs and ranks them according to the percentage of FICs attributed to a particular cause: inadequate pricing/surplus $(23 \%)$; rapid growth $(20 \%)$; affiliate problems $(19 \%)$; and overstated assets $(18 \%)$. The differences in regulation and market forces between the U.S. and the Canadian life insurance industries help to explain why the above causes of insolvency have been less influential in Canada. The issue of undercapitalization has already been mentioned. Canadian insurers also enjoyed greater tax relief with regard to losses on the sale of bonds; ${ }^{14}$ greater deductibility of policyholder dividends; and more flexible non-forfeiture requirements and valuation standards. All of these contributed to less strain on surplus and higher capital ratios than U.S. insurers.

${ }^{14}$ Canadian life insurance companies paying corporate income taxes could offset losses on the sale of bonds by a $50 \%$ tax credit, whereas accounting in the U.S. government statement required that losses on the sale of bonds be fully reflected in surplus without similar taxation relief. 
The issue of affiliate problems was essentially a non-issue in Canada until recently. Prior to 1982, the four "pillars" of the financial services industry - banks, trust companies, life insurance companies, and investment brokers - were very distinct in the activities they could perform. The activities of each were well defined and only recently have the barriers between them begun to come down. Beginning in 1987, banks were allowed to own securities firms and then by 1990 were allowed to acquire trust business. The 1992 Bank Act then completed the circle by allowing banks to hold insurance companies, and vice-versa.

The Canadian Insurance Companies Act (ICA) of 1992 expanded the activities in which insurance companies can participate and gives a list of corporations, primarily in the financial field, in which a life company may have a "substantial investment" 15 but prohibits such investment in other corporations. In addition, the "prudent person" rule was adopted as a guideline for eligible investments; insurance companies are now free to issue senior and subordinated debt; they are permitted to own banks or trust companies and banks are permitted to own insurers as subsidiaries; and it is easier for companies to merge or to demutualize. A preview of the future in terms of the effects of this regulation may be found in Quebec, where provincially chartered financial institutions have been permitted to own multiple financial institutions since 1984. Many life insurers chartered in Quebec took advantage of their expanded powers and over expanded into fields in which they had no expertise. For example, Les Cooperants engaged in an extensive diversification program that involved the acquisition of securities, real estate and trust companies. It is also interesting to note that the downfall of Confederation Life in 1994 was partly attributed to its very unprofitable trust operations, suggesting that problems with affiliates may become a more important issue for Canadian insurers in the future.

Finally, the problem with overstated assets has also been less serious in Canada due to less concentration in risky corporate bonds as well as insurers reporting using Generally Accepted Accounting Principles (GAAP) rather than Statutory Accounting Principles, providing a more accurate measure of the value of assets. Furthermore, MCCSR will also help to assure that insurers that choose riskier investment strategies will hold greater amounts of capital, providing a cushion to help protect the solvency of the company. The need for a very aggressive investment strategy by some U.S. insurers was fuelled by the pressure to earn high interest rates and as discussed earlier, this pressure was less severe for Canadian insurers due to a more gradual shift away from traditional life products and less concentration in guaranteed interest products.

${ }_{15}$ Either $10 \%$ of the voting rights attached to all the outstanding voting shares or, alternatively, when the aggregate of the shares owned of the company directly or indirectly is greater than $25 \%$ of the shareholders' equity of the company. 


\section{REFERENCES}

AMBROSE, J. M. and CARROLL, A. M., "Using Best's Ratings in Life Insurer Insolvency Prediction",The Journal of Risk and Insurance, Vol. 61, No. 2, 1994.

"An Overview of the Canadian Life and Health Insurance Industry", Bank of Canada Review, Spring, 1994.

BARNIV, R. and HERSHBARGER, R. A., "Classifying Financial Distress in the Life Insurance Industry", Journal of Risk and Insurance, 57, 1990, pp. 110-136.

BERNIER, G. and KLEFFNER A. E., "The 1980 Change from Fixed to Variable Rate Policy Loans", prepared for presentation at the American Risk and Insurance Association, 1989.

BRANNON, G. M., "Public Policy and Life Insurance" in The Financial Condition and Regulation of Insurance Companies, 1991.

Canadian Life and Health Insurance Facts.

"Canadian Life and Health Insurance Industry Ratings", Dominion Bond Rating Service, July, 1993.

“Canadian Life Insurance Industry Faces Increased Competition”, BestWeek: Life/Health Supplement, January, 1994.

"Canada's Life and Health Insurers", Department of Finance, Canada, March, 1993.

CEURVORST, K. A., "Canadian Life/Health Insurance Industry Rating Review and Trends”, Duff \& Phelps Credit Rating Co. Insurance Report, March, 1994.

GRAVES, E. E. (Editor), McGill's Life Insurance, The American College, Bryn Mawr, Pennsylvania, 1994.

HUGGINS, K. and LAND, R. D., Operations of Life and Health Insurance Companies, 2d Ed. Life Office Management Association, Inc., Atlanta, GA, 1992.

KOPCKE, R. W. and RANDALL, R. E., "Insurance Companies as Financial Intermediaries: Risk and Return" in The Financial Condition and Regulation of Insurance Companies, 1991.

"Life and Health Insurance: 1990-1991", Industry Profile by the Minister of Industry, Science and Technology and Minister of International Trade, 1991.

Life Insurance Fact Book.

MOLONEY, T. E., "Insurance Companies as Financial Intermediaries: Discussion” in The Financial Condition and Regulation of Insurance Companies, 1991.

PARTRIDGE, J. and SLOCUM, D., “Damage Control at Confed” Globe and Mail, 13 August, 1994.

PEDOE, A. and RUDD, D. S., Life Insurance and Annuities in Canada, 2d Edition, Life Underwriters Association of Canada, Ontario, 1993.

PINKES, K. J. H., "Discussion: The Structure, Conduct and Regulation of the Life Insurance Industry", in The Financial Condition and Regulation of Insurance Companies, 1991.

PINCHES, G. E. and TRIESCHMANN, J., "The Efficiency of Alternative Models for Solvency Surveillance in the Insurance Industry", Journal of Risk and Insurance, 41, 1974, pp. 563-577.

“S. \& P's Canadian Life Insurance Market Report”, Standard \& Poor's Insurance Rating Services, 1992.

SCHNEIDER, R. E., "Discussion: The Structure, Conduct and Regulation of the Life Insurance Industry" in The Financial Condition and Regulation of Insurance Companies, 1991.

WRIGHT, K. M., "The Structure, Conduct and Regulation of the Life Insurance Industry" in The Financial Condition and Regulation of Insurance Companies, 1991. 